\title{
Preparation and Characterization of $\mathrm{Sb}_{2} \mathrm{Te}_{3}$ Thin Films by Coevaporation
}

\author{
Bin Lv, Songbai Hu, Wei Li, Xia Di, Lianghuan Feng, Jingquan Zhang, Lili Wu, Yaping Cai, \\ Bing Li, and Zhi Lei
}

College of Materials Science and Engineering, Sichuan University, Chengdu 610064, China

Correspondence should be addressed to Wei Li, waylee2000@sohu.com

Received 3 April 2010; Accepted 23 June 2010

Academic Editor: Leonardo Palmisano

Copyright $\odot 2010$ Bin Lv et al. This is an open access article distributed under the Creative Commons Attribution License, which permits unrestricted use, distribution, and reproduction in any medium, provided the original work is properly cited.

\begin{abstract}
Deposition of $\mathrm{Sb}_{2} \mathrm{Te}_{3}$ thin films on soda-lime glass substrates by coevaporation of $\mathrm{Sb}$ and $\mathrm{Te}$ is described in this paper. $\mathrm{Sb}_{2} \mathrm{Te}_{3}$ thin films were characterized by $\mathrm{x}$-ray diffraction (XRD), $\mathrm{x}$-ray fluorescence (XRF), atomic force microscopy (AFM), $\mathrm{x}-$ ray photoelectron spectroscopy (XPS), electrical conductivity measurements, and Hall measurements. The abnormal electrical transport behavior occurred from in situ electrical conductivity measurements. The results indicate that as-grown $\mathrm{Sb}_{2} \mathrm{Te}_{3} \mathrm{thin}_{\mathrm{films}}$ are amorphous and undergo an amorphous-crystalline transition after annealing, and the posttreatment can effectively promote the formation of Sb-Te bond and prevent oxidation of thin film surface.
\end{abstract}

\section{Introduction}

It is well known that CdTe thin film solar cell offers one of the most promising photovoltaic devices for terrestrial applications due to the near-optimum bandgap and high absorption coefficient of CdTe. However, forming an ohmic contact to CdTe is very difficult because of the high electron affinity of CdTe and the self-compensation in CdTe. An approach to overcoming these problems is incorporation of $\mathrm{p}^{+}$region materials between $\mathrm{CdTe}$ and the metal electrode to provide the advantageous electrical properties. These materials should have long-term stability of the electrical contact to CdTe and should not cause chemical reactions at the interface. Conventionally, a $\mathrm{Cu}$ layer or a material doped with $\mathrm{Cu}$ is used to form back contacts with a low barrier height. Unfortunately, $\mathrm{Cu}$ will diffuse along the grain boundaries down to the main junction resulting in the degradation of device performance. New material such as antimony telluride possesses the expected characteristics mentioned above, which can provide stable ohmic back contacts to CdTe $[1,2]$.

Antimony telluride is a binary V-VI group compound semiconductor with the form of $\mathrm{A}_{2} \mathrm{~B}_{3}$, which is mentioned as the thermoelectric generators and coolers, and back contacts for photovoltaic devices because of its high Seebeck coefficient, low thermal conductivity, low electrical resistivity, low bandgap, and long-term stability [1-3].

To obtain $\mathrm{Sb}_{2} \mathrm{Te}_{3}$ thin films, a number of techniques have been used in the literature, such as thermal evaporation $[4,5]$, atomic layer epitaxy (ALE) [6], sputtering [2, 7], electrochemical method [8], flash evaporation [9], and metalorganic chemical vapor deposition (MOCVD) [10]. Among all these techniques, coevaporation offers several advantages in the growth of $\mathrm{Sb}_{2} \mathrm{Te}_{3}$ thin films for CdTe solar cells, such as the desirable stoichiometry, simple evaporation equipment, and a relatively short fabrication processing time.

In this study, we describe the preparation, structure, morphology, and electrical properties of coevaporated $\mathrm{Sb}_{2} \mathrm{Te}_{3}$ thin films. These are helpful to fabricate stable CdTe solar cells with $\mathrm{Sb}_{2} \mathrm{Te}_{3}$ back contacts.

\section{Experimental}

$\mathrm{Sb}_{2} \mathrm{Te}_{3}$ thin films were grown by a coevaporation method at room temperature in a high-vacuum chamber with base pressure about $9 \times 10^{-4} \mathrm{~Pa}$. Sb foil (99.999\% purity) and Te powder (99.999\% purity) were evaporated on the glass substrates from two independent sources. The deposition 


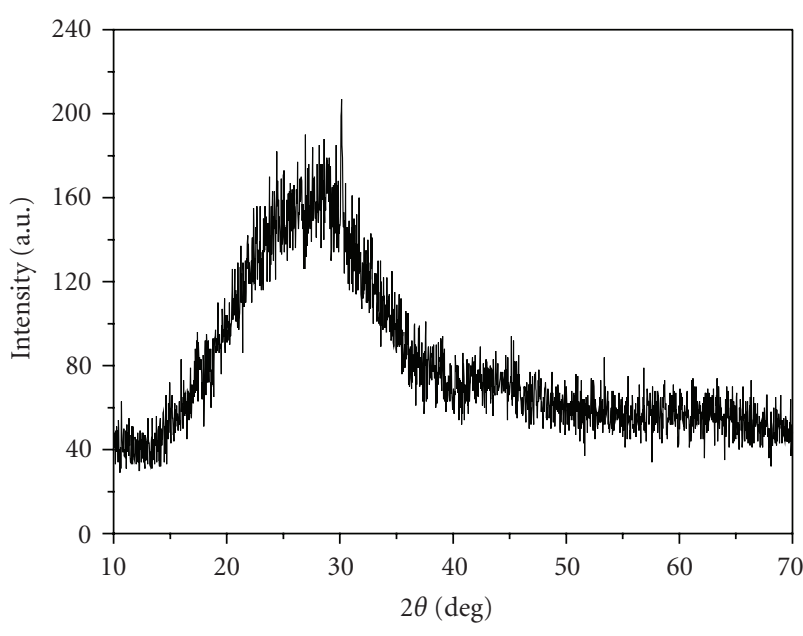

FIgURE 1: XRD pattern of $\mathrm{Sb}_{2} \mathrm{Te}_{3}$ thin films as-deposited.

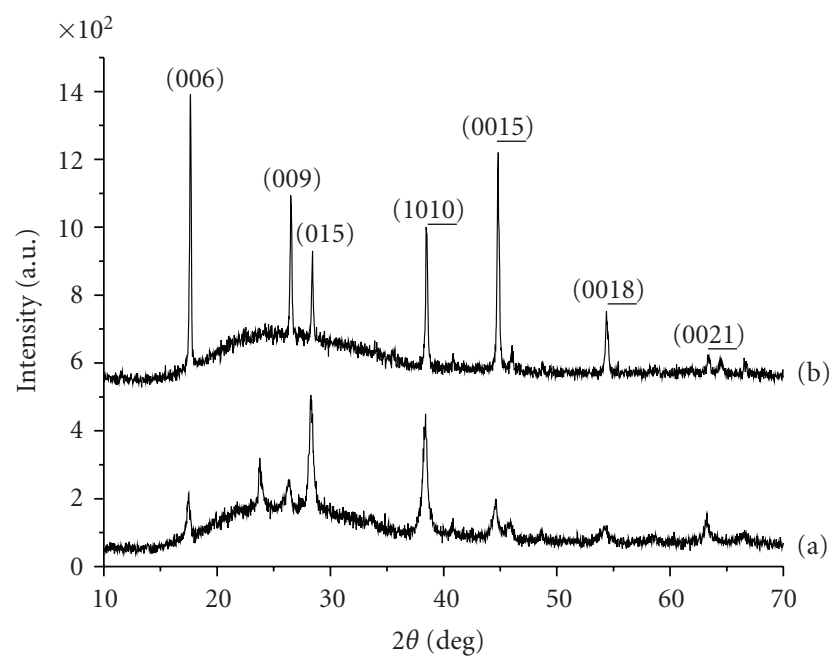

FIGURE 2: XRD patterns of $\mathrm{Sb}_{2} \mathrm{Te}_{3}$ thin films annealed at $473 \mathrm{~K}$ (a) and $613 \mathrm{~K}(\mathrm{~b})$.

rates and the thickness of thin films were independently controlled by two LHC-2 thickness monitors. The substrates were cleaned prior to deposition, and a postdeposition treatment was performed in $\mathrm{N}_{2}$ ambient.

XRD measurements were used to study the $\mathrm{Sb}_{2} \mathrm{Te}_{3}$ structure, and XRF was performed to determine chemical composition of the thin films. Surface analysis of $\mathrm{Sb}_{2} \mathrm{Te}_{3}$ thin films was carried out using XPS, and surface morphology of $\mathrm{Sb}_{2} \mathrm{Te}_{3}$ thin films was observed by AFM. Dark conductivity was measured with electron beam evaporation deposited $\mathrm{Ni}$ strips using two-probe technology. The four-probe Van der Pauw method was used to carry out the Hall measurements to determine the Hall coefficient, mobility, and carrier concentration.

\section{Results and Discussion}

To determine the composition of the Sb-Te alloys, $\mathrm{x}$-ray fluorescence spectra analysis of Sb-Te systems as-deposited

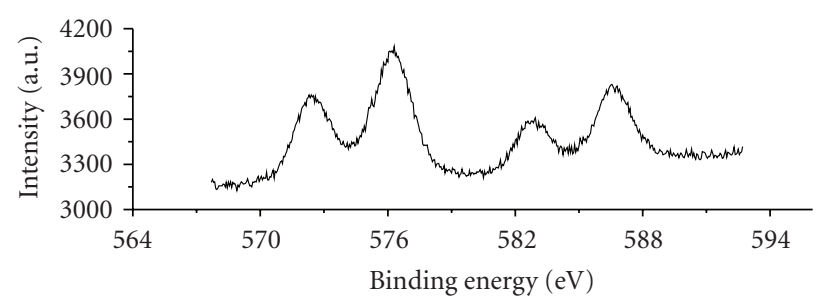

(a)

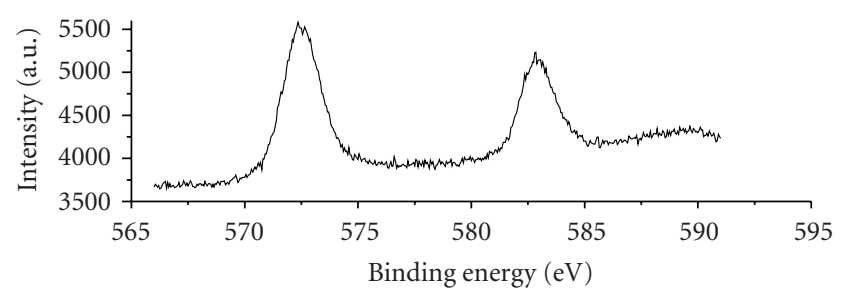

(b)

Figure 3: Te $3 \mathrm{~d}$ spectra for $\mathrm{Sb}_{2} \mathrm{Te}_{3}$ thin films as-deposited (a) and annealed at $613 \mathrm{~K}(\mathrm{~b})$.

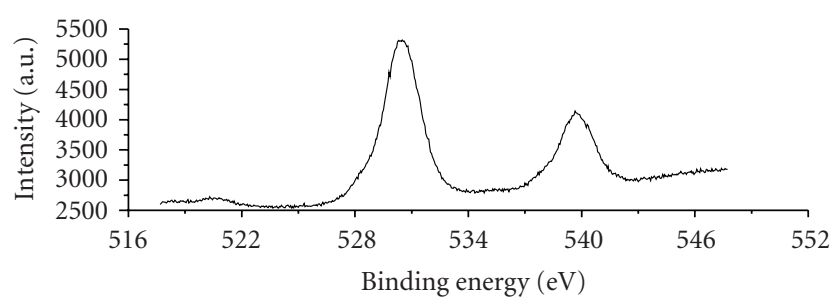

(a)

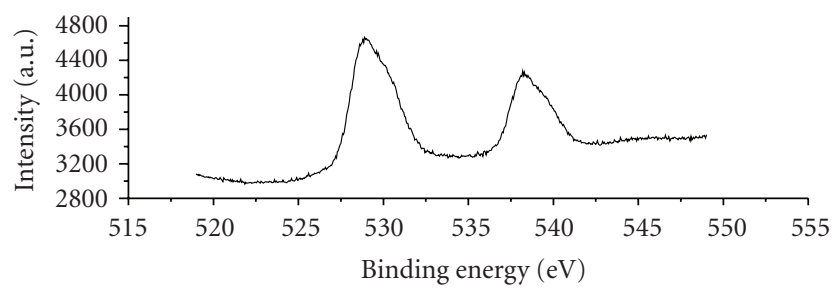

(b)

Figure 4: $\mathrm{Sb} 3 \mathrm{~d}$ spectra for $\mathrm{Sb}_{2} \mathrm{Te}_{3}$ thin films as-deposited (a) and annealed at $613 \mathrm{~K}(\mathrm{~b})$.

was carried out. The contents of two kinds of elements, $\mathrm{Sb}$ and $\mathrm{Te}$, for as-grown thin films from XRF quantitative analysis are 0.0554 and $0.0941 \mathrm{mg} / \mathrm{cm}^{2}$, respectively. The stoichiometric ratio $(\mathrm{Te}: \mathrm{Sb})$ is $1.62: 1$ in the $\mathrm{Sb}_{2} \mathrm{Te}_{3}$ thin films, which is good agreement with the standard value, $1.5: 1$ (a relative error of $10 \%$ is assumed). After annealing, there are not significant changes of stoichiometry in the $\mathrm{Sb}_{2} \mathrm{Te}_{3}$ thin films.

Figure 1 shows $\mathrm{x}$-ray diffraction pattern of $\mathrm{Sb}_{2} \mathrm{Te}_{3}$ thin films deposited by coevaporation at room temperature on the glass substrates. As-deposited $\mathrm{Sb}_{2} \mathrm{Te}_{3}$ films are an amorphous structure. Bätzner et al. [1], and Romeo et al. [2] have reported that $\mathrm{Sb}_{2} \mathrm{Te}_{3}$ thin films as the back contact materials were deposited on a substrate kept at a temperature of $573 \mathrm{~K}$ and, thus, CdTe solar cells with crystalline $\mathrm{Sb}_{2} \mathrm{Te}_{3}$ 
TABLE 1: Hall parameters for $\mathrm{Sb}_{2} \mathrm{Te}_{3}$ thin films.

\begin{tabular}{lccc}
\hline Sample & Mobility $\left(\mathrm{cm}^{2} \mathrm{~V}^{-1} \mathrm{~S}^{-1}\right)$ & Hall coefficient $\left(\mathrm{cm}^{3} \mathrm{C}^{-1}\right)$ & Carrier concentration $\left(\mathrm{cm}^{-3}\right)$ \\
\hline $\mathrm{Sb}_{2} \mathrm{Te}_{3}$ as-deposited & 44.49 & 0.082 & $7.60 \times 10^{19}$ \\
$\mathrm{Sb}_{2} \mathrm{Te}_{3}$ annealed at $613 \mathrm{~K}$ & 169.86 & 0.11 & $5.87 \times 10^{19}$ \\
\hline
\end{tabular}

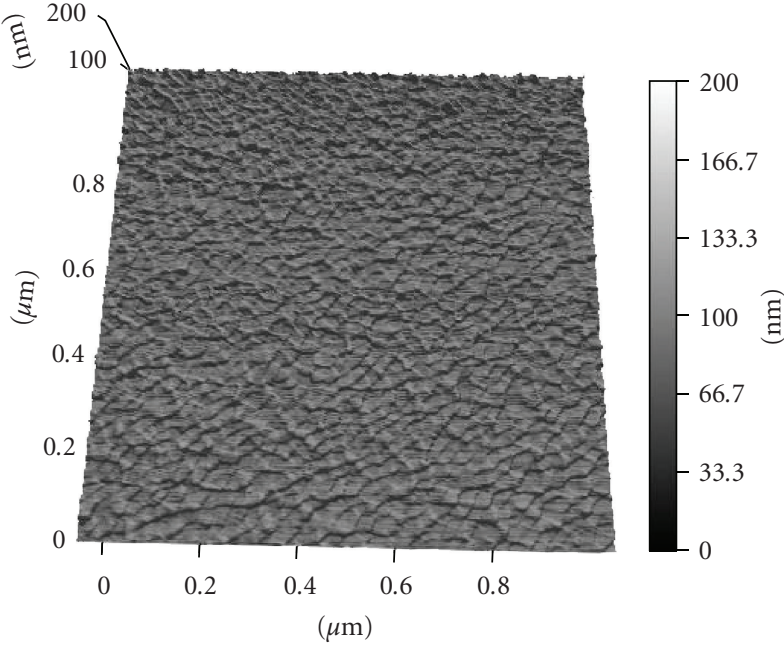

(a)

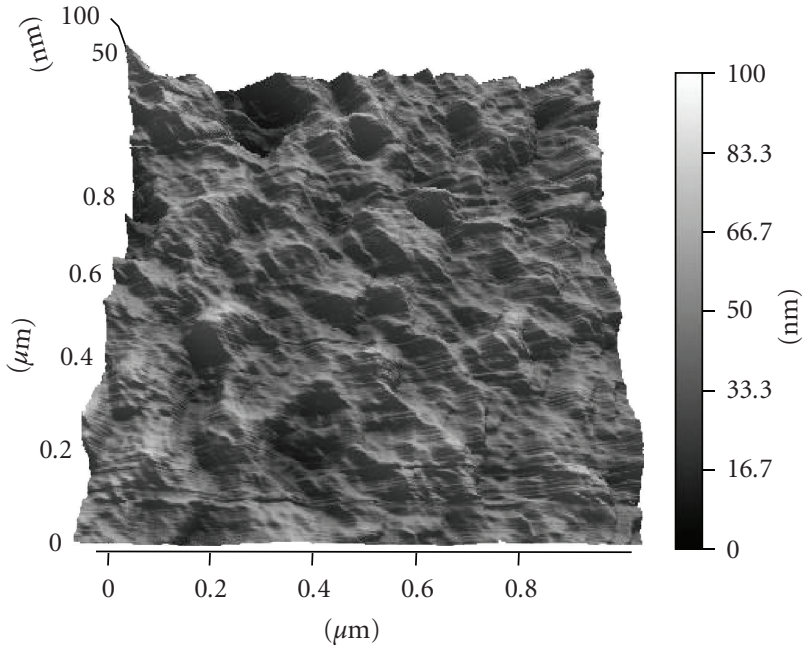

(b)

Figure 5: AFM images of $\mathrm{Sb}_{2} \mathrm{Te}_{3}$ thin films as-deposited (a) and annealed at $613 \mathrm{~K}$ (b).

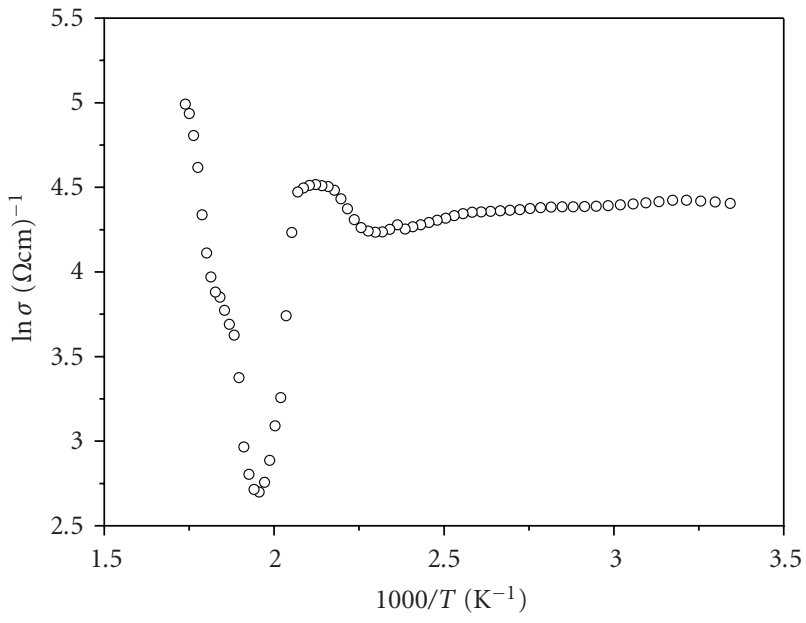

FIgure 6: Temperature dependence of dark conductivity for $\mathrm{Sb}_{2} \mathrm{Te}_{3}$ films.

thin films demonstrated the good device performance. In this work, however, the films were deposited at room temperature, so the postdeposition treatment was desirable for $\mathrm{Sb}_{2} \mathrm{Te}_{3}$ ohmic contact to CdTe. It was found that it had no effect on the $\mathrm{Sb}_{2} \mathrm{Te}_{3}$ amorphous phase after annealing at a low temperature $(<473 \mathrm{~K})$. Then these samples were annealed at a temperature of $473 \mathrm{~K}$ in $\mathrm{N}_{2}$ ambient, whose XRD pattern shown in Figure 2(a) reveals their polycrystalline nature with the peaks corresponding to (006), (009), (015), (1010), (0015), (0018), and (0021) planes of $\mathrm{Sb}_{2} \mathrm{Te}_{3}$. Besides the diffraction peaks of rhombohedra $\mathrm{Sb}_{2} \mathrm{Te}_{3}$, the pattern shows a weak diffraction peak is present at about $2 \theta$ of $23.76^{\circ}$, which could be assigned to the $\mathrm{TeO}_{2}$ due to the oxidation of thin film surface as confirmed by XPS analysis. The thin films were annealed at $613 \mathrm{~K}$ shown in Figure 2(b). The strongest intense line indicates the (006) plane is at about $2 \theta$ of $17.45^{\circ}$, and the additional weak peaks are at about $2 \theta$ of $17.5^{\circ}, 26.4^{\circ}$, $28.4^{\circ}, 40.8^{\circ}, 44.8^{\circ}, 54.5^{\circ}$, and $64.2^{\circ}$ corresponding to the (009), (015), (1010), (0015), (0018), and (0021) planes of $\mathrm{Sb}_{2} \mathrm{Te}_{3}$, while the weak diffraction peak of $\mathrm{TeO}_{2}$ disappears at about $2 \theta$ of $23.76^{\circ}$. From Figure 2, one can see that an effect of the annealing temperature on the structure of the thin films, annealing at a higher temperature, would readily promote the formation of single-phase $\mathrm{Sb}_{2} \mathrm{Te}_{3}$ with very strong (001) preferential orientation and effectively suppress a $\mathrm{TeO}_{2}$ secondary phase.

Figures 3-4 show the XPS spectra of $\mathrm{Sb}_{2} \mathrm{Te}_{3}$ thin films. Te $3 \mathrm{~d} 5 / 2(572.5 \mathrm{eV})$ and $\mathrm{Te} 3 \mathrm{~d} 3 / 2(582.9 \mathrm{eV})$ peaks are observed (Figure 3), which well agrees with the results reported for $\mathrm{Sb}_{2} \mathrm{Te}_{3}$ in the literature [11]. Additional peaks (576.2 and $586.6 \mathrm{eV}$ ) for Te $3 \mathrm{~d}$ shown in Figure 3(a), indicating a chemical environment different from $\mathrm{Sb}_{2} \mathrm{Te}_{3}$, can be ascribed to $\mathrm{Te}-\mathrm{O}$. The Te-O bond does not exist on the film surface after crystallization at $613 \mathrm{~K}$, which indicates that as-deposited thin film surface is much easy to be oxidized after exposure to the atmosphere. For the Sb 3d spectra as shown in Figure 4, the values of $539.6 \mathrm{eV}(3 \mathrm{~d} 3 / 2)$ and $530.3 \mathrm{eV}(3 \mathrm{~d} 5 / 2)$ are ascribed to Sb-O bonding, and 529-530 eV (3d5/2) and 538$539 \mathrm{eV}(3 \mathrm{~d} 3 / 2)$ to $\mathrm{Sb}$ metallic bonding [11, 12]. The Sb $3 \mathrm{~d}$ peaks at 530.5 and $539.7 \mathrm{eV}$ in Figure 4(a) correspond to $\mathrm{Sb}-\mathrm{O}$, which shows that as-deposited film surface easily 
forms antimony oxide. Sb-Te bonds are demonstrated in polycrystalline films (Figure 4(b)) at 528.9 and $538.2 \mathrm{eV}$. Therefore, a postdeposition treatment is an effective method to promote the formation of $\mathrm{Sb}-\mathrm{Te}$ bond and prevent oxidation of thin film surface.

The particle size and morphology of the $\mathrm{Sb}_{2} \mathrm{Te}_{3}$ as a back contact material affect the electrical properties of solar cells. Therefore, it is possible to evaluate the quality of the films by AFM. Figure 5 shows AFM images of $\mathrm{Sb}_{2} \mathrm{Te}_{3}$ thin films as-deposited (a) and annealed at $613 \mathrm{~K}$ (b). The films annealed at a high temperature exhibit larger particles than that as-deposited films, and the root mean square (RMS) values are about $2.3 \mathrm{~nm}$ for as-deposited films and $7.6 \mathrm{~nm}$ for the annealed films. Obviously, the posttreatment process can promote the growth of the films, which is significant to reduce the grain boundary density.

As a good buffer layer between the absorber layer and metal electrode in the CdTe solar cells, the back contact material (e.g., $\mathrm{Sb}_{2} \mathrm{Te}_{3}$ ) is generally an intermediate degenerated semiconductor, which increases the conductivity and creates a tunneling barrier. So we studied the electronic properties of $\mathrm{Sb}_{2} \mathrm{Te}_{3}$ thin films from the Hall measurements. Table 1 shows the parameters for $\mathrm{Sb}_{2} \mathrm{Te}_{3}$ thin films such as mobility, Hall coefficient, and carrier concentration. The thin films asdeposited and annealed at $613 \mathrm{~K}$ are p-type semiconductor compounds and have high carrier concentrations, $7.60 \times$ $10^{19}$ and $5.87 \times 10^{19} \mathrm{~cm}^{-3}$, respectively. Although the carrier concentration decreases slightly, the mobility of the $\mathrm{Sb}_{2} \mathrm{Te}_{3}$ thin films increases after the heat treatment, which means that the polycrystalline $\mathrm{Sb}_{2} \mathrm{Te}_{3}$ thin films have higher conductivity than amorphous ones and the thin films without $\mathrm{Cu}$ doping are suitable to form a $\mathrm{p}^{+}$-region layer to reduce the barrier height.

Meanwhile, electrical conductivity measurements were made on as-deposited $\mathrm{Sb}_{2} \mathrm{Te}_{3}$ thin films in the temperature range $300-650 \mathrm{~K}$. The plot of conductivity versus temperature is shown in Figure 6. The conductivity decreases slowly with increasing temperature in the lower temperature range and reaches the minimum values at $433 \mathrm{~K}$, and then it increases. This kind of change may be attributed to the oxidation of $\mathrm{Te}$ or $\mathrm{Sb}$ on the surface of the thin films as evidenced by the XRD and XPS studies. Above $473 \mathrm{~K}$, however, the conductivity decreases at a rapid rate and subsequently increases after passing the minimum at a temperature of $523 \mathrm{~K}$. It indicates that the films undergo a phase transition, from amorphous to crystalline between 473 and $523 \mathrm{~K}$. This is consistent with XRD spectra (see Figures 1 and 2). Similarly, this irreversible behavior has also been observed on Sb-Te and Se-Te alloy systems [13, 14].

\section{Conclusions}

$\mathrm{Sb}_{2} \mathrm{Te}_{3}$ thin films were prepared by the vacuum coevaporation technique, together with posttreatment. As-grown thin films, which are oxidized easily in air, are an amorphous phase. After annealing the polycrystalline $\mathrm{Sb}_{2} \mathrm{Te}_{3}$, thin films having a rhombohedra structure were obtained. An abnormal temperature dependence of conductivity was observed in the temperature range $300-650 \mathrm{~K}$, which shows that an amorphous-crystalline phase transition occurs in the thin films. Annealed at a high temperature can prevent effectively the oxidation of the thin films and increase obviously the mobility of thin films.

\section{Acknowledgment}

This work was supported by the Science and Technology Program of Sichuan Province, China (Grant no. 2008GZ0027).

\section{References}

[1] D. L. Bätzner, A. Romeo, M. Terheggen, M. Döbeli, H. Zogg, and A. N. Tiwari, "Stability aspects in CdTe/CdS solar cells," Thin Solid Films, vol. 451-452, pp. 536-543, 2004.

[2] N. Romeo, A. Bosio, R. Tedeschi, A. Romeo, and V. Canevari, "Highly efficient and stable CdTe/CdS thin film solar cell," Solar Energy Materials and Solar Cells, vol. 58, no. 2, pp. 209218, 1999.

[3] D. M. Rowe, CRC Handbook of Thermoelectrics, CRC Press, 1995.

[4] A. M. Farid, H. E. Atyia, and N. A. Hegab, "AC conductivity and dielectric properties of $\mathrm{Sb}_{2} \mathrm{Te}_{3}$ thin films," Vacuum, vol. 80, no. 4, pp. 284-294, 2005.

[5] H. Zou, D. M. Rowe, and S. G. K. Williams, "Peltier effect in a co-evaporated $\mathrm{Sb}_{2} \mathrm{Te}_{3}(\mathrm{P})-\mathrm{Bi}_{2} \mathrm{Te}_{3}(\mathrm{~N})$ thin film thermocouple," Thin Solid Films, vol. 408, no. 1-2, pp. 270-274, 2002.

[6] J. Y. Yang, W. Zhu, X. H. Gao, X. A. Fan, S. Q. Bao, and X. K. Duan, "Electrochemical aspects of depositing $\mathrm{Sb}_{2} \mathrm{Te}_{3}$ compound on Au substrate by ECALE," Electrochimica Acta, vol. 52, no. 9, pp. 3035-3039, 2007.

[7] A. E. Abken and O. J. Bartelt, "Sputtered $\mathrm{Mo} / \mathrm{Sb}_{2} \mathrm{Te}_{3}$ and $\mathrm{Ni} / \mathrm{Sb}_{2} \mathrm{Te}_{3}$ layers as back contacts for CdTe/CdS solar cells," Thin Solid Films, vol. 403-404, pp. 216-222, 2002.

[8] I. Y. Erdoğan and U. Demir, "Synthesis and characterization of $\mathrm{Sb}_{2} \mathrm{Te}_{3}$ nanofilms via electrochemical co-deposition method," Journal of Electroanalytical Chemistry, vol. 633, no. 1, pp. 253258, 2009.

[9] H. S. Soliman, S. Yaghmour, and H. G. Al-Solami, "Heattreatment effect on the structural and optical properties of flash evaporated $\mathrm{Sb}_{2} \mathrm{Te}_{3}$ thin films," European Physical Journal Applied Physics, vol. 44, no. 1, pp. 59-64, 2008.

[10] R. Venkatasubramanian, T. Colpitts, E. Watko, M. Lamvik, and N. El-Masry, "MOCVD of $\mathrm{Bi}_{2} \mathrm{Te}_{3}, \mathrm{Sb}_{2} \mathrm{Te}_{3}$ and their superlattice structures for thin-film thermoelectric applications," Journal of Crystal Growth, vol. 170, no. 1-4, pp. 817-821, 1997.

[11] M.-J. Shin, D.-J. Choi, M.-J. Kang et al., "Chemical bonding characteristics of $\mathrm{Ge}_{2} \mathrm{Sb}_{2} \mathrm{Te}_{5}$ for thin films," Journal of the Korean Physical Society, vol. 44, no. 1, pp. 10-13, 2004.

[12] S. S. Garje, D. J. Eisler, J. S. Ritch, M. Afzaal, P. O’Brien, and T. Chivers, "A new route to antimony telluride nanoplates from a single-source precursor," Journal of the American Chemical Society, vol. 128, no. 10, pp. 3120-3121, 2006.

[13] Z. S. El Mandouh, "Structure and electrical properties of vacuum-deposited antimony telluride thin films on an amorphous substrate," Journal of Materials Science, vol. 30, no. 5, pp. 1273-1276, 1995.

[14] V. Damodara Das and P. Jansi Lakshmi, "In situ electrical conductivity and amorphous-crystalline transition in vacuumdeposited amorphous thin films of a $\mathrm{Se}_{50} \mathrm{Te}_{50}$ alloy," Journal of Applied Physics, vol. 62, no. 6, pp. 2376-2380, 1987. 


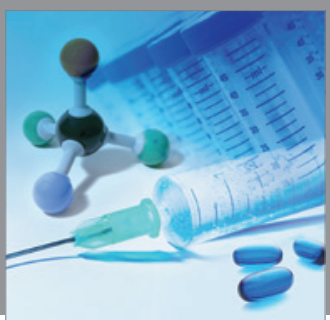

International Journal of

Medicinal Chemistry

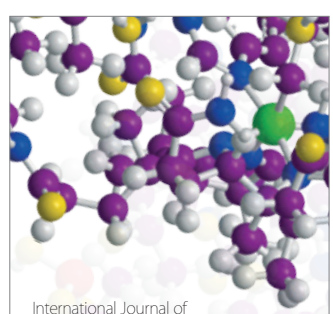

Carbohydrate Chemistry

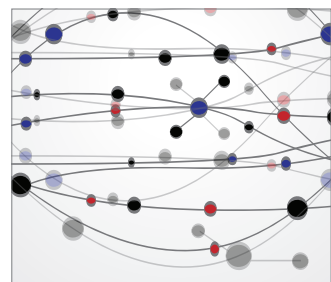

The Scientific World Journal
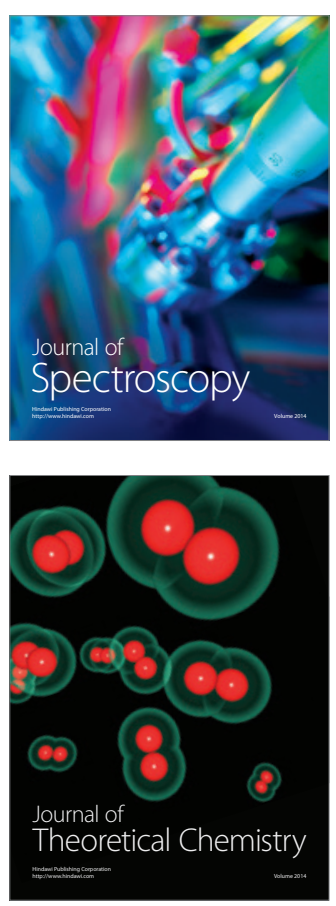
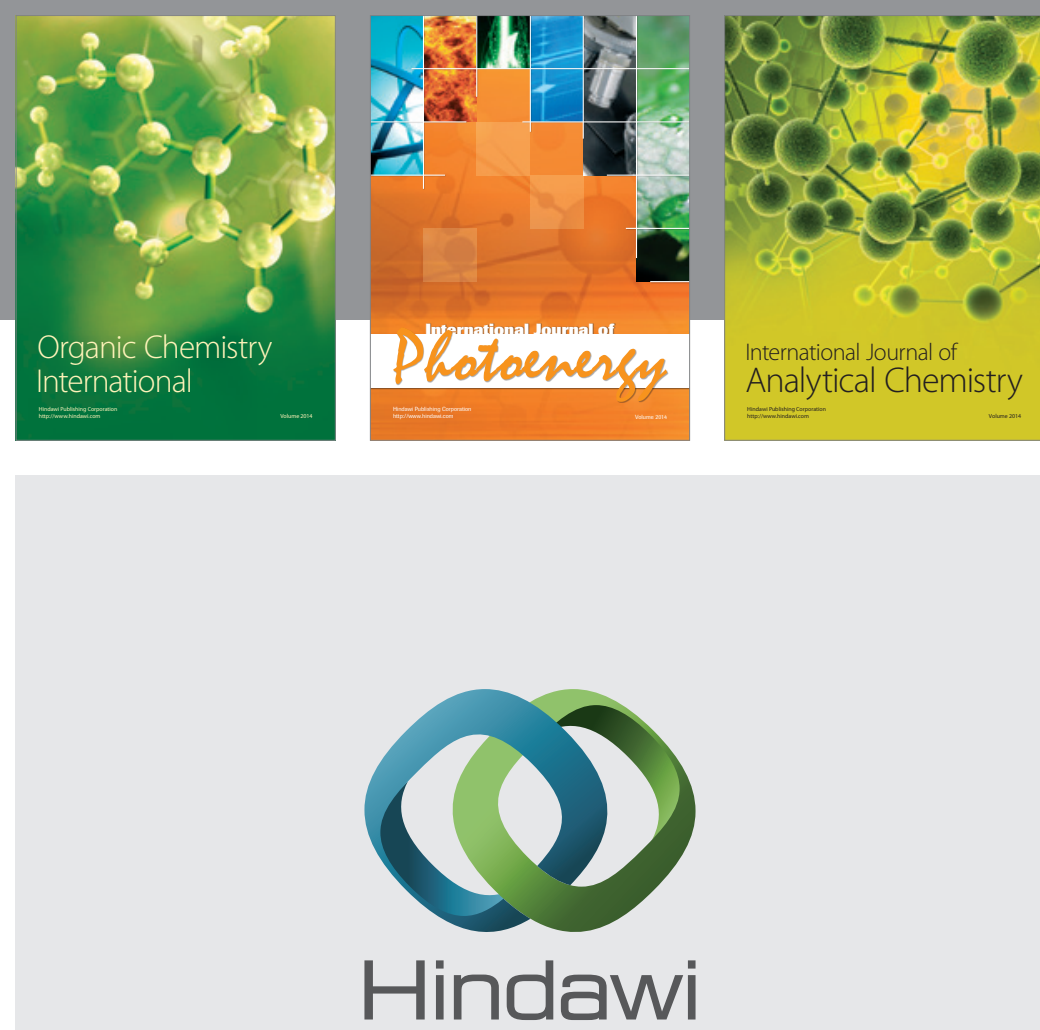

Submit your manuscripts at

http://www.hindawi.com
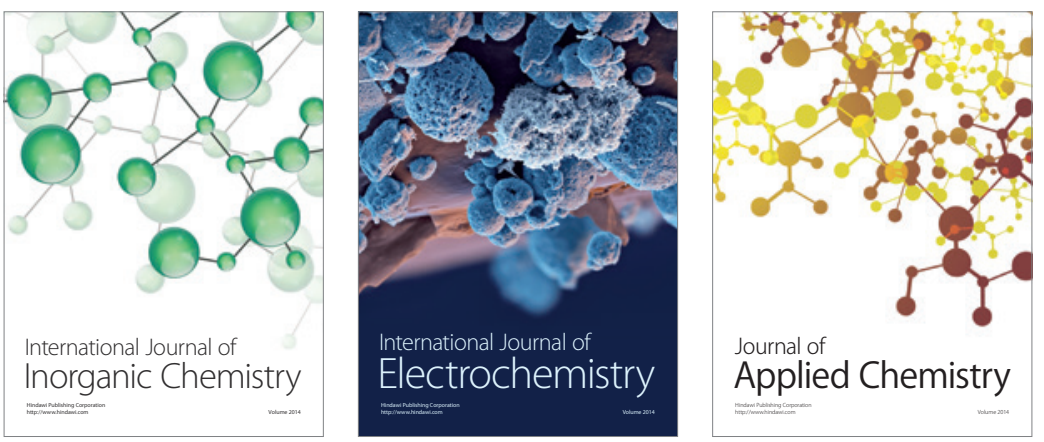

Journal of

Applied Chemistry
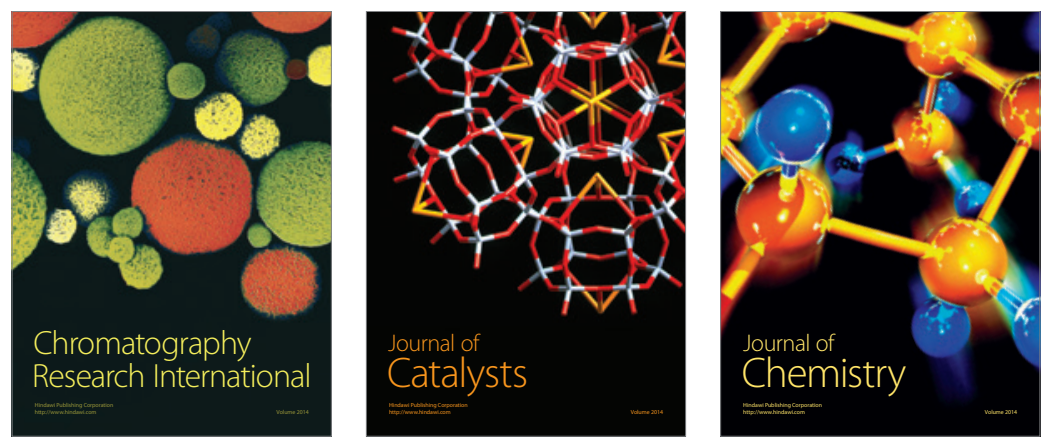
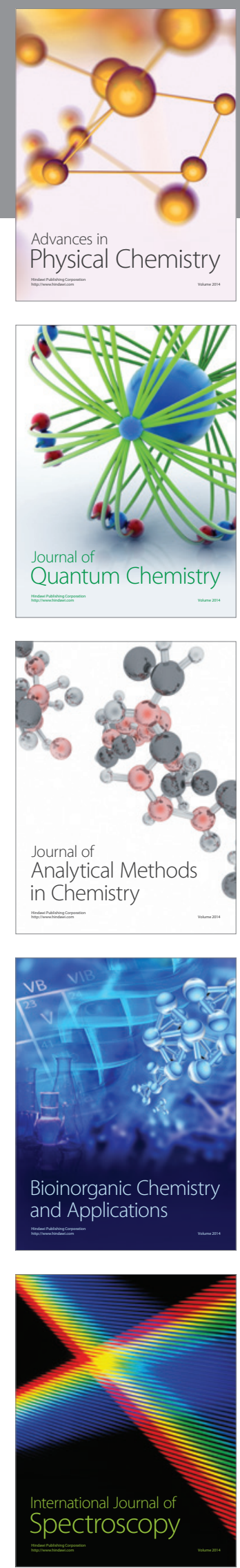